\title{
Midwives of Sixteenth-Century Rural East Anglia
}

\author{
J U L I A A L L ISO N \\ The University of Nottingham, University Park, Nottingham, NG7 2RD, UK \\ fulia.Allison@nottingham.ac.uk
}

\begin{abstract}
This study identifies more than fifty previously unrecorded Elizabethan, East Anglian rural midwives. Their professional lives are discussed in terms of licensing and oaths, knowledge, skills, caseload, travel, networking and years of practice. In regard to their family life, matters examined include marital status, spousal occupation, children, social standing, age at death and testacy. Finding and researching these midwives involved examination of a large number of different kinds of archive documents, including sixteenth-century parish registers and quarter session records. As data were examined a clearer picture emerged of these early midwives and their practice.
\end{abstract}

\section{Introduction}

The midwives who practised in the time before medical men entered the field of midwifery in rural areas have yet to have their lives fully explored. David Cressy acknowledges that 'the little we can learn of the social status of midwives sets them in the heart of the social order'. ${ }^{1}$ David Harley argues that 'midwives, in particular, remain a mute group, and most of the evidence on them emanates from hostile contemporary accounts'. He further maintains that the historic role of the midwife has been underestimated. ${ }^{2}$ This prosopographical study of a geographical cohort seeks to establish a profile for midwives in sixteenth-century rural East Anglia, including their family and professional lives. Midwives from across rural, coastal, East Anglia were identified. ${ }^{3}$ However, the level of detail available on the personal lives and professional practice of individual midwives varies considerably. Professional activities are discussed in terms of licensing and oaths, knowledge, skills, caseload, travel, networking and years of practice. Their personal lives will be considered with reference to family life, marital status, spousal occupation, homes, children, social standing, age at death and testacy.

It is important to clarify that although the licensing of doctors began in the sixteenth century, this research failed to reveal any archive in which there was mention of a doctor, physician, barber surgeon or apothecary in connection with any birth in the rural parishes of this study. Likewise no evidence was found of an opinion being sought by a court or coroner regarding pregnancy, labour or birth from any person other than 
a midwife. Midwives were apparently the only sixteenth-century maternity care givers in rural East Anglia. It is also clear that gentry and wealthy families used the services of local midwives. Midwife Margaret Lynsey attended Lady Cromwell at her country home in North Elmham, Norfolk. ${ }^{4}$ Midwife Mistress Fiske of Binham, Norfolk, attended gentlewoman Mistress Calthorpe, ${ }^{5}$ and the accounts of Nathanial Bacon, suggest that a local midwife attended his wife, Anne, at home in Stiffkey. ${ }^{6}$

\section{Finding and researching early rural midwives}

Evenden and Harley retrieved licensing material for their studies of seventeenth-century midwives, ${ }^{7}$ but no extant licences have been found for sixteenth-century midwives in rural East Anglia. The midwives for this study were located through examination of a large number of different kinds of archive documents, particularly parish registers and quarter session records. More than fifty named and eight unnamed midwives were identified, some of whom were born in the fifteenth century and some of whom continued practice into the seventeenth century. ${ }^{8}$ In some cases the name was all there was to discover but in others it was possible to reconstitute a midwife's family. Midwives Elenor Nightingale, Agnes Cache and Margaret Burwood were among those found in bastardy hearings or parish registers whose family it was possible to reconstruct, to a greater or lesser degree.

\section{Elenor Nightingale}

Midwife Elenor Nightingale's name was found in a bastardy document. She was born about 1549. In 1575 she married Jonas Nightingale, yeoman and glover, at Great Wenden, Essex. ${ }^{9}$ Their first three children were baptised at Great Wenden. Around 1580 the family moved to Newport, Essex; between 1581 and 1592 seven more children were born. Their last-born child Gratia died aged eighteen months, but the remaining nine children all lived into adult life. ${ }^{10}$ Elenor had a remarkable childbearing history with ten pregnancies in fifteen years with no stillbirths or early infant deaths. Newport parish register is one of few known to include stillbirths and miscarriages. Evidence shows that she practised into old age because she attended a base birth in $1615 .{ }^{11}$ By the time of her death in 1619 , she had at least nine grandchildren and was outlived by her husband Jonas. ${ }^{12}$ Midwives were also discovered in parish registers. The following two examples show the information that can be uncovered with persistent detective work.

\section{Agnes Cache}

Midwife Agnes Cache appears in White Notley baptism register when she baptised a newborn at home. In 1542 it is recorded that 'William Cache commonly called Redd Hedd Cache and Agnes Cannon were marryed the fourthe day of June'. The vicar's forethought in describing William Cache as 'Redd Hedd Cache' made it possible to distinguish his children from those of another man named William Cache. In 1543 both men had a child baptised. While the father of one child is described as 'Redd Hedd Cache', the other is described as 'Sloppe Cache'. ${ }^{13}$ Sloppes were large baggy trousers, 
so presumably this was a comment on his sartorial presentation. Although there is no record of his occupation, William was a juror at Witham Petty Sessions. ${ }^{14} \mathrm{He}$ died in 1574, leaving money to his children and wife Agnes. ${ }^{15}$ It was not possible to trace Agnes by remarriage or death.

\section{Margaret Burwood}

Midwife Margaret Burwood's name was found in the parish register of Wells, Norfolk. She was buried on $12^{\text {th }}$ August 1598: 'Margaret Burwood widdowe being aboute the age of 95 yeres her whole life upright, She was a mydwife gratious, for mercy detains any woman under her hand. She was devoute, charitable to her abilities a good keeper of hospitality'. ${ }^{16}$ Comment, of any description, is rarely found in parish registers and, although there is detail of ships and men who were lost at sea, the life of no other man or woman in sixteenth-century Wells was acknowledged in this manner.

Margaret was born around 1503. She married Thomas Burwood and gave birth to five children, Thomas, John, Agnes, Margerie and Margaret. Her children all married during Elizabeth's reign and eighteen grandchildren were born. Margaret's husband Thomas died in 1578 at the age of about seventy-nine. In 1587 her grandson Ambrose was lost at sea: '1587 Ambrose Burwood, in this yere being left with a shippe in Norway was never heard of since'. A year later, Margaret's daughter Margerie died. ${ }^{17}$ Margaret died in 1598 and she appointed her children, John, Agnes, and Margaret, as executors. ${ }^{18}$ Her will was signed by more than nine witnesses, including eight women whose names were a roll call of eminent citizens of Wells, including Ann, wife of Andrew Grogan ship owner, and Margaret, widow of William Congham ship owner. ${ }^{19}$ Last to sign was the vicar, Robert Knapp, and after his signature he wrote 'and others'.$^{20}$ A year later, Margaret's grandson Robert Burwood was installed as curate of Wells. ${ }^{21}$ At the time of her death Margaret had four living children, eighteen grandchildren and ten great-grandchildren. She was undoubtedly an exceptional woman and midwife from a socially well placed family.

\section{Midwives' licensing and oaths}

Evidence was sought for licenses and for incidents of misconduct by midwives and women who illegally 'held themselves out as midwives', ${ }^{22}$ but no extant licences were found for sixteenth-century rural East Anglian midwives. Carter reports the 'thin record' of physicians, surgeons and midwives for Norfolk in the early Norwich Subscription Books and the only record of an early midwife is that of Angell Marck who was licensed in $1706 .^{23}$ There is, however, evidence that licensing was taking place from the early Elizabethan period. This comes in the form of action taken against unlicensed women who practised midwifery. Prosecution for practising without licence is recorded in Act Books and court documents. Such records indicate not only that licensing was taking place but that women were being monitored and brought to account for practising illegally.

One of the earliest known English midwife's oaths was taken by Eleanor Pead, ${ }^{24}$ who in 1567 swore to 'faithfully and diligently exercise the said office according to such cunning and knowledge as God has given me'. ${ }^{25}$ It is not clear whether this implies that she was 
divinely endowed with skills or that there was some form of instruction for which evidence no longer exists. It is probable that recommendations from women she attended were also required to establish her competency. The obligation to use her knowledge and skills to help both poor and rich could be viewed as a pious requirement of her religious life but it probably had more to do with ensuring that she delivered women of all social classes, especially those experiencing a base birth. Furthermore she swore that she would 'not suffer a labouring woman to name any than the true father of the child' and she would not 'allow any woman to give birth in secret'. This she was to achieve by ensuring 'that two or three other honest women were present', who, along with the midwife, could demand to know the name of the child's father, to report to the magistrate. ${ }^{26}$

In relation to the preparations for birth, the instruction that 'there were always two or three lights [candles] ready' has both practical and sinister connotations. Given the lack of illumination in a Tudor chamber on a moonless night, the midwife would need extra lighting, especially at the moment of birth. ${ }^{27}$ This requirement is also related to the requirement not to use 'ungodly means to shorten the labour' or 'suffer the substitution of the infant at birth'. ${ }^{28}$ Clearly, an unscrupulous midwife was potentially in a position to supply a living infant, by substitution, to a woman whose child was stillborn. However this was a difficult offence to commit without co-conspirators. Infants were not born every day or even every week in rural localities, and it could be a considerable time before a midwife was able to supply a live child to replace a stillborn one. The injunctions not to use 'ungodly means to shorten the labour' or 'use sorcery or incantation' were probably intended to discourage midwives from attempts to practise witchcraft, herbal decoction or the rupturing of membranes to induce labour or abortion. Such actions could be employed to hasten a birth, in the rare case of a woman whose infant was intended for substitution. Candles ensured that everyone present could see what was happening. No cases of suspected infant substitution were identified but these are historically very rare.

The midwife also swore that she 'would not destroy or dismember an infant', the notion being that she might dismember an infant to facilitate birth in cases such as hydrocephaly or obstructed labour. ${ }^{29}$ In later centuries, midwives who used such processes were seen to be usurping the surgeon's role. She also swore to 'baptize any new-born, in the time of necessity, using the accustomed words and plain, pure water'. Finally her parish priest was required to testify to her life and reputation, and confirm that she was a regular communicant. ${ }^{30}$ Evidence that midwives were practising according to an oath can be found in baptisms carried out at home. This is an example from the Chelmsford register from 1555: 'Johane and Jane Adams daughters of Robert Adams was christened at home by the mydwyfe and was buryed the iii ffebruarye'. ${ }^{31}$ In White Notley, 'Matthewe son Thomas Tomson of Cressinge was christened by Agnes Cache Mydwyef in the house privately and brought to the church and ther received the XIIIth day July 1560 '. ${ }^{32}$ Further evidence that licences were issued is seen in the 1603 Archdeaconry of Colchester Act Book, which reports that Judith Smith presented her certificate to the parishioners at Great Horkesley parish church. ${ }^{33}$

Those who failed to obtain licences or comply with their oath were called before Bishop or magistrate. A single entry in an Act Book of 1597 is the only reference that identifies Goodwife Porter, wife of John Porter of Alresford, as midwife. She had clearly irritated 
her vicar when he noted that she would 'sometimes be mydwyf and sometimes not!!' The exclamation marks are his. ${ }^{34}$ In 1608 her husband John Porter died and his will shows that his wife had predeceased him. He left property to their sons and an annuity to their daughter Margaret until she reached the age of twenty-one years, indicating that Goodwife Porter had left at least one young child when she died. ${ }^{35}$ Her apparent failure to carry out her duty in 1597 may therefore have been due to declining health. Women who were not licensed were similarly held to account. For example, in 1612 the wife of John Sparling of Totham Magna was called before the Bishop for professing herself to be a midwife without licence. However, the Bishop clearly saw the case involving the wife of a man named Gee of West Ham, Essex as more serious when in 1565 she was excommunicated 'for taking upon her to be a midwife unlicensed, to maintain Alice Amans' whoredom by that act'. ${ }^{36}$ Perhaps her punishment was intended as a warning to other women intent upon practising illegally and assisting women who gave birth to bastards to evade the law. No other documents relating to the Gee family or Alice Amans were found.

What remains unclear is why these noncompliant women, who were obviously being called to attend confinements, did not themselves seek to become licensed. Perhaps local women would not recommend them or the vicar would not sponsor them because of a misdemeanour, recusancy or failure to attend church regularly. An archive search failed to show that any women who were practising illegally, or their husbands, left a will. Likewise, they do not seem to have had family members holding positions in the community, such as constable, churchwarden or juror, as was often the case with licensed midwives. Perhaps their lack of social standing made them unsuitable in the eyes of the church. More simply, it may have been that there was a fee for licensing that these women could not afford. The licensing of midwives served ecclesiastic purposes by ensuring that frail new-borns were baptised. It also served the law by eliciting the father's name in a base birth, to indemnify the cost to the parish of keeping the child. More importantly, the licensing of midwives served parturient women, despite the fact that the church may not have seen this as its primary function.

\section{Marital status of midwives}

It has been suggested that early midwives were usually widows who needed to work for a living. ${ }^{37}$ With the exception of two midwives, for whom there was no evidence to determine marital status, all midwives in the study were married and a few were widows at the point in their lives at which they were identified. On average, a marriage lasted from seventeen to nineteen years before the death of one or other partner. ${ }^{38} \mathrm{~A}$ different picture emerges among midwives in this study. In the case of midwives married before the introduction of parish registers in 1539, it is difficult to estimate duration of marriage other than in the case of Margaret and Thomas Burwood. The trail of register entries indicates a marriage of some fifty-one years before Thomas died. Margaret lived on for another twenty years, but did not remarry. Margaret Pullen was the only midwife in the study who remarried after the death of her first husband. ${ }^{39}$ Evidence indicates that midwives such as Margaret Pullen practised during their married life and continued in 
practice after they were widowed. Others, such as Goodwife Porter predeceased their husbands. ${ }^{40}$

\section{Midwives' homes and spousal occupations}

Identifying midwives' homes and spousal occupations helps to broaden the picture of their lives. It has been suggested that early midwives were relatives of artisans and traders who lived in small houses attached to their work premises. ${ }^{41}$ Midwives in this study, whose homes were identified, lived in different circumstances. Elenor Nightingale of Newport lived in a mansion house with her husband. ${ }^{42}$ Midwife Porter of Alresford and her husband lived in a farmhouse called 'Knops'. ${ }^{43}$ Margaret Pullen and her husband lived in a house at White Colne called 'Sixpence'. ${ }^{44}$ Mistress Fiske of Binham, Norfolk, and her husband, lived in a house described as having a hall with a saffron kiln, parlour, chamber and upstairs chambers. ${ }^{45}$ Although it is not clear where midwife Joan Gen, a widow of Bury St Edmunds, Suffolk, lived, she instructs in her 1562 will that her 'two tenements with appurtenances in 'Longe [unreadable]' be sold to provide for generous bequests made in her will. ${ }^{46}$ Midwife Agnes Cache probably lived in a house named Le Tyehouse, which was acquired by her husband before their marriage. ${ }^{47}$ Finally in the case of midwife Margaret Leffingwell, a document records her exact address as 'Poters on Stowe Road in Stowe Maries, Essex'. ${ }^{48}$

Research into midwives' histories also revealed spousal occupations. Midwives Grace Bridge, Dorothy Odwinns and Elenor Nightingale were married to yeomen; ${ }^{49}$ Dennys Parkar and Goodwife Porter to husbandmen; ${ }^{50}$ Mistress Fiske to a farmer and saffron producer; ${ }^{51}$ Margaret Pullen married a wealthy landowner; ${ }^{52}$ Winifred Smyth a weaver, ${ }^{53}$ and Ann Cook was a vicar's wife. ${ }^{54}$ In addition, some midwives had husbands, brothers, fathers, sons, grandsons or in-laws who held positions in the local or wider community including justice of the peace, ${ }^{55}$ juror ${ }^{56}$ constable ${ }^{57}$ and priest. ${ }^{58}$ The names found in Elizabethan court documents are usually either gentry or criminals, with the majority of ordinary rural citizens seldom appearing. It is therefore interesting to find the number of occasions when members of midwives' families occur in jury lists, witnesses and church appointments, perhaps reinforcing the public-spirited nature of these families.

Information uncovered about individual midwives ranges from a detailed family history to nothing more than a name in a parish register. Table 1 summarises what is known about the lives of thirteen midwives in the study, including husbands, marriage, children, number of years of practice and testacy. Duration of practice was difficult to establish since a midwife may have practised for years before her name appeared in a court document so the years of practice shown in Table 1 are those for which there is evidence. Eight midwives practised for an average of at least thirty-three years. The exception, in terms of evidence of practice, is Margaret Burwood, who lived until her ninety-fifth year and was still described as a midwife. Assuming that her practice did not begin until her family was complete, she nevertheless practised for some fifty years. ${ }^{59}$ Midwives whose ages are known or could reasonably be estimated lived to a good age, with the exception of midwife Porter who died when her children were young. ${ }^{60}$ Several midwives were 
Table 1

Thirteen Midwives by Children, Years of Marriage, Years of Practice, Age at Death and Testacy

\begin{tabular}{lllll}
\hline Midwife & Children & Years Marriage & Years Practice & Age at Death \\
\hline Audrey Benet $\dagger$ & 1 known & $?$ & $>40$ & $>85$ \\
Margaret Burwood $\dagger$ & 5 & 51 & c. 50 & $95 \mathrm{~W}$ \\
Agnes Cache & 4 & 32 & $>29$ & $>60$ \\
Emma Cooper BH & $?$ & $?$ & 22 & 72 \\
Sarah ffelton $*$ B.H. & 4 & $?$ & c. 50 est. & 86 \\
Mother Lamberd $\dagger$ B.H. & 1 known & $>40$ & $>20$ & $>75$ \\
Elenor Nightingale $\dagger$ B.H. & 10 & 44 & $?$ & 70 \\
Johane Norwood $\dagger$ & 4 & $?$ & $?$ & c. $70 \mathrm{~W}$ \\
Dorothye Odwinns B.H. & 1 known & $?$ & $?$ & $>80$ \\
Dennys Parkar & 4 & 47 & c. 30 & $77 \mathrm{~W}$ \\
Midwife Porter & 3 & $>20$ & $?$ & $>45$ \\
Margaret Pullen $\dagger$ B.H. & 4 & married twice & $>20$. & c. $70 \mathrm{~W}$ \\
Ann Robensone $\dagger$ & 2 & $?$ & $?$ & c. $70 \mathrm{~W}$ \\
Average & & 38 & $>33$ & c. 73 \\
\hline
\end{tabular}

c.- Any midwife for whom no burial record can be found but evidence of adult grandchildren exists is given an estimated age at death of seventy years, based on an average age at marriage of twenty-six years.

$>$ - Where no burial record or family can be traced, a midwife is given the age she was at the date of the last verifiable account.

$\dagger$ - These are midwives who were born before commencement of parish registers in 1539 , or in a parish for which registers are no longer extant.

* Midwife whose practice began at the end of Elizabeth's reign.

W- Indicates those midwives for whom a will was found. Midwives who predeceased their husband seldom left a will.

$\mathrm{BH}$ - Indicates those midwives who were identified in a bastardy-hearing document.

widows for whom there was insufficient evidence to make a reasoned estimation of their age at death. Average age at death, of those whose age could be assessed was seventythree years. It is clear that, in a time when life expectancy is said to have been low, all of these women lived beyond the average life span. ${ }^{61}$ Given that they had a home and financial security, they appeared to enjoy a comfortable life by standards of the day. The social and economic profiles, including marital and social status and children, of these rural, sixteenth-century midwives were similar in many ways to those of the seventeenthcentury London midwives in Evenden's study. ${ }^{62}$

\section{Base birth and sixteenth-century midwives, in perspective}

Six midwives were identified in bastardy hearings although only one, Margaret Pullen, attended two cases in her long working life. Margaret lived close to Earles Colne, which has been described as a bastardy prone society in the late sixteenth century. ${ }^{63}$ In a study of six East Anglian parishes in this period, seventy-eight base infants were born, of which only three became the subject of a bastardy hearing. It is therefore not surprising to find that most midwives of the period never attended such a case and while these 
hearings can give insight into life in sixteenth-century East Anglia, their importance to the average citizen or midwife should not be overstated. Base birth rates in sixteenthcentury England are estimated at around two per cent, ${ }^{64}$ although Cressy suggests that the measured percentage was lower in Eastern England. ${ }^{65}$ The majority of base born infants did not become the subject of court orders because either the father supported his infant or married the mother or the mother was associated with a group of wandering travellers. Nonetheless these cases remain one of the few resources where the spoken words of ordinary and poor sixteenth-century citizens can still be heard.

\section{Literacy of rural midwives}

It is apparent from wills and court documents signed with their mark, ${ }^{66}$ as well as letters written on their behalf, ${ }^{67}$ that none of the rural midwives in this study was able to write. As late as 1641 a letter to the magistrate was written for a midwife by a butcher and signed with her mark. The earliest document signed by a midwife was dated $5^{\text {th }}$ January $1654 / 5{ }^{68}$ While there is no evidence whether the midwives in this study were able to read, it appears unlikely on the balance of probability, since little printed material was available in the course of everyday life in rural areas. ${ }^{69}$ In addition, all their wills and those of their husbands were signed with a mark. The exception could be midwife Ann Cooke, who was married to the vicar of Grays Thurrock who may have taught her to read. ${ }^{70}$ The presumed inability of sixteenth-century midwives to read or write has been used to denigrate their professional knowledge and skills. Stone has argued that 'childbirth was a very dangerous experience, for midwives were ignorant and ill trained, and often horribly botched the job, while the lack of hygienic precautions meant that puerperal fever was a frequent sequel'. ${ }^{71}$ It has also been said that midwives were 'completely ignorant of the most elementary facts of anatomy and obstetrics' and 'illiterate and untrained', ${ }^{72}$ and Armstrong lays the blame for high maternal mortality in Elizabethan Cumbria firmly at the door of 'dirty and inept midwives' ${ }^{73}$ Yet it is a mistake to use literacy as a measure of the intelligence, knowledge or skills of early midwives, since documentary evidence indicates that men of ordinary and yeoman families in sixteenth-century rural East Anglia were likewise unable to write. Laslett reports that only eleven per cent of women in Norfolk between 1580 and 1726 were able to sign their name. ${ }^{74}$ Even in noble families, writing was not a skill that came easily to some women. Nathaniel Bacon drafted his wife Anne's correspondence for her to copy. ${ }^{75}$

\section{Midwives' knowledge and skills}

It could be argued that the knowledge and skills of early rural midwives were built upon direct experience of childbirth and an inherent desire to assist childbearing women. Sixteenth-century rural dwellers lived close to nature; some midwives were married to yeomen, husbandmen or farmers, who employed both farm workers and servants. Births, whether her own or those of kinsfolk or of an employee's wife, were an intrinsic part of everyday life. Given the number of women who attended any birth, it is clear that first-hand experience of confinement was not hard to come by. ${ }^{76}$ Regardless of whether 
they could read or write, these midwives demonstrated knowledge and understanding of their profession in court when they calculated the expected date of confinement, relating it to dates of unlawful carnal knowledge given by the mother of the base child and the ecclesiastical calendar. In 1579 midwife Katherine Sylvester of Harford Stock attended Susan Dates. She reported to the court that 'Susan was delivered of her child, being a man child, on the Friday before St Michael the Archangel last past, which is from St Stephens day 39 weeks and 1 day'. ${ }^{77}$ It could be argued that the church's influence permeated all aspects of the midwives' practice down to the need to express pregnancy calculations by saints' days. Yet a perusal of other quarter session documents indicates that dates were often expressed in this manner at this time.

In some bastardy cases, however, the midwife was faced with an impossible challenge. In 1582 midwife Agnes Trewe of Coggeshall asked labouring, single woman Susan Babye to name her child's father. Susan first named her brother Edward, then she confessed to having lain with John Fletcher at Witham Fair. Later she added that she had 'had to do' with William Dagnett of Coggeshall about 'our Ladye daye was twelvemoneth' and finally she confessed that Richard Howe had 'once to do with her a fortnight before Midsummer last'. ${ }^{78}$ There is no evidence to show which man was brought to account for maintenance of the child but, apparently unbeknown to the midwife or Susan, four days earlier John Fletcher had appeared before the magistrates charged with paternity of the child of Dorothy Clarke of Burnham. ${ }^{79}$ Unfortunately the outcome of these hearings are missing and Coggeshall folios for 1582 are lost from the baptismal register, so we may never know who was found to be the father of Susan's child. ${ }^{80}$ This case clearly demonstrates the shortcomings of this punitive system of exacting the name of a man to indemnify the parish purse.

It is clear from baptisms carried out by midwives at the time of birth that midwives were able to identify those infants unlikely to survive. Midwife Agnes Cache baptised three infants in White Notley. ${ }^{81}$ A common cause of early infant death was prematurity. At that time the chance of survival of an infant less than thirty-six weeks gestation was poor. An experienced midwife would be able to tell from the size of the child and any appearance of immaturity, such as the presence of lanugo, translucent skin and rapid breathing, that early baptism was advisable. ${ }^{82}$ Likewise if the birth had been difficult or the child was born with an abnormality, such as a neural tube defect or gross deformity, the midwife would perform the baptism. The fact that many of the infants baptised at home by a midwife succumbed within a few days indicates the midwives' ability to detect infants at risk.

Evidence from archive documents shows that rural East Anglian midwives generally practised alone except for gossips or witnesses, and usually in the woman's home. It was previously believed that a sixteenth-century midwife 'would have no knowledge whatsoever, prior to the labour, of what exactly presented itself beneath the mother's voluminous skirts', until she attended her in labour. ${ }^{83}$ Nonetheless some evidence of care during pregnancy was found. In a bastardy case regarding the paternity of the child of a single woman, Sarah Campian of Great Dunmow, it was reported and affirmed by another woman present that midwife Dorothy Odwinns 'was there near 11 weeks in her house... as well before her labour as at the time thereof'. ${ }^{84}$ Clearly there was a need for the 
midwife to be present prior to the birth despite the fact that the woman was unmarried. Whatever the problem, mother and child survived. Sarah's child was baptised at Great Dunmow parish church. ${ }^{85}$

No evidence was found that rural midwives in this study used clyster-pipes or decoctions to facilitate labour, ${ }^{86}$ but there was also no evidence of any midwifery training or apprenticeship. ${ }^{87}$ Emmison notes the absence of medical treatises in any Essex will of the period. He further reports that there were only seven clerical wills in which books were bequeathed and comments that 'the illiteracy of most of the Elizabethan people is fairly well known'. ${ }^{88}$ None of the wills left by the midwives in the study included bequests of books, birth stools or chairs, instruments or equipment of a midwife's profession. Given that contemporary wills included such items as kettles, pillows, jugs and candlesticks, it seems likely that books, which were very valuable, and equipment would have been mentioned if they existed. The midwives' oath contained an explicit obligation 'Not to use ungodly means to shorten the labour' and there is no indication in any account of base births or other transcripts that any method of induction, whether by instrument or drug, was employed. As far as evidence allows us to know, it appears that these East Anglian midwives were employing the time honoured practice of allowing nature to take its course. ${ }^{89}$ This, in turn, is known to reduce the incidence of infection, haemorrhage and death. ${ }^{90}$

It has been suggested that some younger midwives followed their mothers into the work, ${ }^{91}$ yet no evidence was found in wills, registers or archive documents of a familial tendency to practise. However, since the total number of midwives who were practising across rural East Anglia in the sixteenth-century is not known, it is not possible to ascertain the percentage represented by this study and whether there were other midwives whose daughters did follow them into the profession.

\section{Midwives' practical experience and travel}

It has been suggested that in this early period rural midwives attended relatively few births each year due to the low birth rate in many parishes and that as a result their practical experience was limited, compromising their ability to undertake difficult births. ${ }^{92}$ Such claims tend to overlook key factors. Observation and hands-on participation play a significant part in training midwives for their role and although no amount of practical experience can prepare for every possible complication, the cumulative experience of years of continuous practice and witness would give a midwife who undertook twenty to thirty deliveries a year a substantial level of expertise, and particularly the ability to detect when a labour was not following the normal course. Two unnamed midwives in Pentlow recognised their need for further assistance when they summoned a third midwife, Mother Lamberd, to a difficult birth in $1589 .{ }^{93}$

The division of baptisms in any year by available midwives is also misleading because the deliveries would inevitably be unevenly spread for several reasons. An experienced midwife might reduce the number of women to whom she gave care, or temporarily give up her practice because of ill health, or pregnancy. Likewise family illness or old age might limit her practice to family members and established clients only, in which case 
other midwives would need to increase their caseload. ${ }^{94}$ The number of pregnancies in any year in any parish could change over time due to demographic changes, an influx of new residents, disease or famine and this would be reflected in a midwife's activity. For example, baptismal entries in the parish of Clare in Suffolk suggest that one midwife would have had a caseload of fourteen births per annum in the period from 1583 to 1587 , whereas in the preceding five years her caseload would have been twenty-nine births per annum. ${ }^{95}$ Moreover, such calculations take no account of the fact that midwives attended births outside their parish and some parishes did not record stillbirths or late miscarriages in the baptismal register, although both required attendance by a midwife. It also fails to take account of the fact that, on occasion, several midwives attended a difficult birth adding to each midwife's experience and number of witness births. With this in mind, the case made for a strategy of dividing number of baptisms per annum in given areas by the number of midwives in that area is unrealistic. ${ }^{96}$

The material examined for this project revealed examples of midwives who travelled outside their home parish to attend women of all classes in labour. In 1579 midwife Katherine Sylvester of Ingatestone, Essex, attended a base birth in Stock, a round trip of eight miles and in 1589 Mother Lamberd travelled a round trip of eight miles across the border from Suffolk to Pentlow in Essex to attend a difficult birth. ${ }^{97}$ In 1601 elderly midwife Margaret Pullen of Gaines Colne, Essex, was called to Earls Colne some three miles away to attend a base birth. ${ }^{98}$ Midwives also went outside their parish to deliver married parishioners. White Notley register indicates that Agnes Cache attended women in Cressing Temple and Faulkbourne, four miles away, while Shalford register shows that midwife Elizabeth Callys attended women in Wethersfield, two miles away. ${ }^{99}$ Midwives also travelled to attend wealthy or important clients. In 1599 midwife Mistress Fiske of Binham, Norfolk, travelled a round trip of six miles with her servant to attend Mistress Calthorpe of Cockthorpe, wife of the Captain of the Militia. ${ }^{100}$ However, no account of a midwife's willingness to travel in order to fulfil her duties equals the story of the elderly midwife Dennys Parkar, who undertook a round trip of some twenty miles on foot in order to attend a prisoner who was awaiting execution with her husband for theft and also find a wet nurse for the orphaned infant. These sixteenth-century midwives appear to have travelled much as did the seventeenth-century midwife in Kendal who left the earliest known diary of her deliveries. ${ }^{101}$

Walking was a way of life to rural dwellers. Medieval and early sixteenth-century pilgrims walked from all over the country to the shrine at Walsingham, Norfolk, and students walked for miles to attend university. ${ }^{102}$ There are archive examples of pedestrian travellers of every description: vagrants; servant girls; sailors and soldiers; and 'walking women'. ${ }^{103}$ The latter included a young woman in labour who was dismissed by her employer and sent to walk with an old woman to her father's house some four miles away; she gave birth in a field en route. ${ }^{104}$

Despite the fact that highways were little more than dirt tracks and often impassable in wet weather, particularly in marshy areas, walking was the common form of travel for most rural citizens during Elizabeth's reign and the most reliable way of achieving a destination. ${ }^{105}$ It is thus unsurprising that midwives often travelled on foot outside their parish to fulfil their role. This evidence casts doubt on not only previous assumptions 
about the number of cases a midwife attended annually, but also the supposition that every village had its own midwife. There is no reason why a midwife would be engaged from as far as ten miles away if there were another nearer, or that midwives from another parish would be summoned to attend a base birth if that parish had its own midwife. ${ }^{106}$ Another record indicates that there was more than one midwife working in Great Coggeshall, which had sixty to ninety baptisms a year in the late sixteenth century. ${ }^{107}$

\section{Women who attended base births with midwives}

It was not only midwives who were prepared to travel some distance to attend a birth. In the bastardy case attended at Wethersfield by midwife Elizabeth Callys of Shalford, the witnesses Katherine Crosse, Rose Ringer and Bytteris Burles had also travelled from Shalford and were all young married women, two of whom had given birth in recent years. ${ }^{108}$ Among the female witnesses present at the base birth attended by Mother Lamberd at Pentlow were three wives of husbandmen, Clemence Jervis, Alse Lumly and Margaret Shelly, who were all resident in Pentlow. Also in attendance were Alse and Anne Hardie, wives of husbandmen Richard and Christopher Hardie of Belchamp St. Paul, and a widow, Ann Carter of Foxearth, together with two other unnamed midwives. ${ }^{109}$ Several interesting features arise from this record; only three of the witnesses were resident in Pentlow, while Alse and Anne Hardie lived at Belchamp St Paul, a hamlet west of Pentlow, a short distance from Clare. In 1574 Mother Lamberd's daughter Anna had married Roger Hardie so it is possible that the witnesses Alse and Anne Hardie were Mother Lamberd's in-laws. The final witness Ann Carter lived in a village situated several miles to the east of Pentlow. ${ }^{110}$ It is interesting to speculate about why these particular women were chosen, who contacted them and how they travelled from so wide a geographical area. There were three midwives present at the birth and they may each have brought their own witnesses, in accordance with their oath. On the other hand some of these women may have expressed an interest in becoming a midwife and thus been prepared to travel for first-hand experience of a difficult birth. This case provides evidence of professional cooperation and networking between midwives.

\section{Networking among midwives and professional support}

This is the only birth found for this study where more than one midwife is reported to have been present at a labour and birth. ${ }^{111}$ Pentlow was a small hamlet largely comprised of estates of wealthy families, with an average of six births a year during Elizabeth's reign. There is no evidence of a resident midwife. When attempts to deliver the child of vagrant Alse Matthewe by two unnamed midwives failed, midwife Mother Lamberd was summoned from across the county border in Suffolk whereupon, despite the delay in labour, she succeeded in delivering a live infant and mother. Mother Lamberd may have given the woman small ale to rehydrate her and encouraged her to rest or change position: perhaps from lying to kneeling. In the case of the fetus lying in a position that hindered delivery, she may have turned the child externally. Conversely, she may 
simply have brought calm and reassurance to the labouring woman by taking control of a room full of women. This case shows that midwives were not only aware of each other's existence but were willing to assist one another in an emergency. Furthermore they recognised those among them who were midwives of expert talent. This professional support network probably pertained, where needed, at the delivery of any woman to whom a midwife gave care but information on this only appears in the court transcript of one 'base birth'. ${ }^{112}$

Another case of a midwife using her professional network involved midwives Dennys Parkar and Audrey Benet. The records suggest Audrey Benet lived in Stansted Mountfitchet all her life, and it appears that she was married with at least one child before the registers began. She was widowed shortly afterwards and did not marry again. ${ }^{113}$ In 1558 at Stansted Mountfitchet church Dennys Constable married Richard Parkar, and in 1560 their first child was born. Dennys and Richard Parkar moved to Birchanger, an adjoining parish, some time after the birth of their third child in 1572.

Audrey Benet and Dennys Parkar clearly knew each other all their lives, and it is probable that midwife Benet delivered Dennys Parkar's daughters and encouraged her to become a midwife. In 1602 midwife Parkar needed to find a wet nurse for the infant of a woman who had been executed. ${ }^{114}$ A wet nurse must have recently given birth, and it is significant that midwife Parkar, whose home was in Birchanger, walked with the child to Stansted Mountfitchet where midwife Benet probably knew of a suitable woman. ${ }^{115}$ At this time Stansted Mountfitchet had more than twenty baptisms a year, while Birchanger was only a hamlet. ${ }^{116}$ Parish registers for Birchanger began in 1680 and even at that time there were only a few baptisms each year. ${ }^{117}$ Thus midwife Parkar may not have known of a lactating mother in Birchanger who was prepared to take the infant. The burial register of Stansted Mountfitchet may hold the secret to what became of the child, '1609, A child kept by Margaret Smith (whose name and parents are unknown) buried'. ${ }^{118}$ This strange entry was unique among registers read for the study. Margaret Smith died shortly after the child, probably from infectious disease, but by all accounts these midwives were committed to their chosen profession and care of mother and child.

\section{Misdemeanours}

F. G. Emmison, former Essex County Archivist, notes that 'midwives very seldom figured in Act Books in terms of having committed a misdemeanor', and this is reflected in the findings of this study. ${ }^{119}$ Given the nature of the midwives' oath, and the rigorous manner in which women were brought before magistrates or bishops for comparatively minor misdemeanours, it is surprising that no reports were found of indiscreet behaviour by midwives in this study. No evidence was found of infant substitution or of a midwife using sorcery or witchcraft with a pregnant or labouring woman. Women and men, accused of witchcraft and sorcery, were regularly brought to trial in Elizabethan courts charged with bewitching animals, or of destroying someone's possessions by magic, and more seriously with bewitching and killing children and adults. ${ }^{120}$ It appears that, in this regard, sixteenth-century, East Anglian midwives respected their oath 'not to use sorcery or incantation'. 121 


\section{Payment to midwives}

The only recorded payments to a midwife relate to the noble Bacon family in North Norfolk. The first account is a gratuity of a piece of gold sent by Lady Anne Bacon to an unnamed midwife on the safe delivery of her granddaughter. ${ }^{122}$ Later, in 1575 , the following entry appears in Nathaniel Bacon's household account, 'payments to the ... smith, minstrels, and midwife'. ${ }^{123}$ No evidence was found of payment for services to any other midwife in the study. Some parish registers contain accounts of parish relief but no record of a payment to a midwife for attending a base birth was found. However, since there are no notes or accounts left by midwives, and the majority of householders were unable to write, lack of documentation does not imply that midwives were not remunerated, in cash or kind, for their service to married ordinary and yeoman families. Conversely it is a surprise to find that midwives may not have been paid for attendance at base births, which may have been viewed as part of their Christian duty under their oath, to help rich and poor.

\section{Recruitment of midwives and continuity of midwifery service}

There is little evidence to show how midwives were recruited or trained to obtain a licence, or how a continuous midwifery service was ensured when the parish midwife died or became too old or ill to work. However, insights can be found here and there. There is evidence that midwife Dennys Parkar of Birchanger knew midwife Audrey Benet in the adjacent parish of Stansted Mountfitchet and midwife Benet may have been influential in encouraging her to take on the role of midwife. ${ }^{124}$ Likewise, two midwives in north Essex were clearly aware of the existence of Mother Lamberd in Clare, and a bastardy case document tells us that there was more than one midwife in Coggeshall. ${ }^{125}$ In the early 1600s Margaret Leffingwell appears to have moved to Stow Maries and taken on the role of midwife. ${ }^{126}$ There is no evidence of her marital status, nor could her birth, marriage or death be identified in the Stow Maries parish register or any other register searched for this study. Leffingwell was an unusual name, although there are a large number of people named Leffingwell in Elizabethan registers of White Colne. ${ }^{127}$ No will or record of her death could be found. Similarly Elizabeth Callys appears to have moved from another parish and become a midwife in Shalford.

There is evidence that a continuous midwifery service was provided in a number of East Anglian parishes into the seventeenth century. In Brentwood, Essex, midwife Joan Lenard was practising in 1616 when she was called to give evidence in a case of suspected witchcraft. ${ }^{128}$ Further archives show that she was still in practice in 1625 when she attended a base birth. ${ }^{129}$ However by 1646 the midwife of Brentwood was named as Dorothy Hannings. ${ }^{130}$ In 1667, in yet another bastardy document, the named midwife of Brentwood is Mary Grub. ${ }^{131}$ Another record indicates that there was more than one midwife working in Great Coggeshall in the late sixteenth century since when midwife Agnes Trewe was called to give evidence regarding a base birth she is described as 'one of the midwives of Coggeshall'. ${ }^{132}$ Despite the limitations of this data there was clearly a pattern of continuity of practising midwives in some parishes. 


\section{Conclusion}

Midwives in sixteenth-century East Anglia have been described, insofar as archive material allows, in terms of their marital, social, economic and professional lives. With the exception of two midwives for whom no evidence of marital status exists, they were all married women or widows with children of their own. While men and women from all walks of life, trades and professions were frequently called before the Quarter Session for minor misdemeanours, no case was found where a licensed midwife was brought before a Magistrate or Bishop for suspected malpractice. It is clear that a licensed midwife's reputation was viewed as beyond reproach by the courts, and her opinion on matters related to pregnancy and childbirth was regarded as the 'expert opinion' of a 'good, honest, creditable and discreet' woman whose own professional interests were best served by maintaining an unstained reputation. ${ }^{133}$ These sixteenth-century midwives exhibited those attributes seen as appropriate in a woman of the times, typified in the tribute to Margaret Burwood in Wells parish register. ${ }^{134}$ Clearly she was a woman of faith and high moral standards who conducted her life honourably. Given that midwives were licensed and accountable to the parish priest, obliged by their oath to be regular communicants and to attend base births, graciousness, charity and devotion could be seen as intrinsic facets of the role of sixteenth-century midwives.

A sixteenth-century woman, unless titled, had no automatic identity in her own right; reference tended to made in terms of her relationship to her husband or lack of husband. To be described as 'midwife' gave a woman a respected identity of her own. Conversely it could be argued that the midwives' oath made them agents of the church in resolving issues such as the paternity of base infants and in baptising sick new-borns, but it also made them at least in part responsible for the punishment inflicted on the unmarried women they delivered. Nonetheless, court and jury made clear the value they placed on the knowledge and skills of a midwife in such cases as that of a servant of Henry Mopted of Frinton, where the jury found that her child 'was born dead through her negligence in not seeking a midwife's help'. ${ }^{135}$

Far from there being a midwife in every town and village, the evidence of this study points to the fact that midwives sometimes travelled many miles to support another midwife or to care for women in labour and that some parishes had no resident midwife. With this in mind, it is likely that some midwives undertook and witnessed well in excess of twenty-five deliveries per annum. While lack of evidence of payment for their services does not mean that they were not remunerated, it appears that some of these midwives were practising for reasons other than financial need. The evidence of networking between the midwives and the continuity of parochial midwifery services over time could be viewed as an early step towards a cohesive rural midwifery service, including apprenticeship and training. No licensing documents for sixteenth-century midwives in East Anglia have been found and without Quarter Session records, parish registers and Archdeaconry Act Books, the names of these women would have remained hidden. The profile of the sixteenth-century rural midwives found for this study shows them to have been wives and mothers who for the most part lived to a good age and practised for decades. No less literate than most sixteenth-century rural citizens, they were married to, or widows of, men of good social standing and were respected by the courts and women they served. In 
terms of practice, they were, by all appearances, using a non-interventionist approach to managing labour and undoubtedly played a role in facilitating the population upturn in Elizabeth's reign.

\section{Supplementary material}

The supplementary material referred to in this paper can be found online at journals.cambridge.org/RUH/10.1017/S0956793315000138

\section{Notes}

1. David Cressy, Birth, Marriage and Death: Ritual, Religion, and the Life-cycle in Tudor and Stuart England (Oxford: Oxford University Press, 1997; repr. 1999), pp. 59-61.

2. David Harley, 'Provincial Midwives in England: Lancashire and Cheshire 1660-1760', in Hilary Marland, ed., The Art of Midwifery: Early Modern Midwives in Europe (Abingdon, 2005), pp. 27-48.

3. Julia Allison, 'Elizabethan Midwives: Beliefs, Practices and Outcomes of Childbearing in Rural East Anglia' (unpublished doctoral dissertation, University of Manchester, 2013).

4. Norfolk Record Office, PD 209/1.

5. Victor Morgan, Jane Key and Barry Taylor, eds, The Papers of Nathaniel Bacon of Stiffkey: 1596-1602, volume 4 (Norwich, 2000), p. 101.

6. A. Hassell Smith and Gillian M. Baker, eds, The Papers of Nathaniel Bacon of Stiffkey: 1556-1577, volume 1 (Norwich, 1979), pp. 53, 57, 61, 65, 76.

7. Doreen Evenden, The Midwives of Seventeenth-Century London (Cambridge, 2000); Harley, 'Provincial Midwives'.

8. See 'Early midwives found for this study' See supplementary online material.

9. Essex Record Office, D/P 389 1/1.

10. ERO, D/P 15/1/1.

11. ERO, Q/SR 211/99.

12. ERO, D/P 15/1/1.

13. ERO, D/P 39/1/1.

14. ERO, D/DK/T233/8.

15. ERO, D/ABW 9/97.

16. Norfolk Record Office, PD 679/1.

17. NRO, PD 679/1.

18. NRO, ANW, will register, Lyncolne, folio. 338.

19. A. Hassell Smith and Gillian M. Baker, eds, The Papers of Nathaniel Bacon of Stiffkey, 1578-1585, volume 2 (Norwich, 1983), p. 146.

20. Wells parish register records the baptism of more than twenty infants born to women who witnessed her will.

21. NRO, PD 679/1.

22. This is an archaic term used to describe women who fraudulently claim themselves to be midwives.

23. E. H. Carter, The Norwich Subscription Books: A Study of the Subscription Books of the Diocese of Norwich, 1637-1800 (Edinburgh: Thomas Nelson and Sons, 1937), p.135.

24. Jean Towler and Joan Bramall, Midwives in History and Society (London, 1986), pp. 56-7.

25. E. M. Thompson and W. H. Frere, Registrum Matthei Parker (Canterbury and York Society, 1928), p. 472.

26. See p. 000, 'Women who attended base births with the midwives'. 
27. Julia Allison, Delivered at Home (London, 1996), pp. 81-2. This practice had a long history. Even into the 1960 s, women were instructed by the 'list of requirements for the district midwife' to ensure that they had candles for an emergency, such as a power cut.

28. Patricia Crawford, Parents of Poor Children in England 1580-1800 (Oxford, 2009), p. 1.

29. Allison, 'Elizabethan Midwives', p. 174.

30. Jean Donnison, Midwives and Medical Men: A History of the Struggle for the Control of Childbirth (New Barnet, 1988), p. 19.

31. ERO, D/P 94/1/1.

32. ERO, D/P 39/1/1.

33. ERO D/AZ 1/2; ERO, D/P 205/1/1.

34. ERO, D/AZ/1/10.

35. ERO, D/ABW 30/107.

36. F. G. Emmison, Elizabethan Life: Morals and the Church Courts (Chelmsford, 1973), p. 320.

37. Donnison, Midwives and Medical Men, p. 21.

38. Laurence Stone, The Family, Sex and Marriage in England: 1500-1800 (Harmondsworth, 1977), p. 46.

39. ERO, D/ACW 5/265.

40. ERO, D/ABW 30/107; ERO, D/P 15/1/1.

41. Towler and Bramall, Midwives in History and Society, p. 65.

42. ERO, D/ABW 50/159.

43. ERO, D/ABW 30/107.

44. ERO, D/ABW 3/210.

45. Victor Morgan, Jane Key and Barry Taylor, eds, The Papers of Nathaniel Bacon of Stiffkey, 1596-1602, volume 4 (Norwich, 2000), pp. 101-2.

46. Suffolk Record Office, Bury St Edmunds, IC500/1/17.

47. ERO, D/DK/T233/8.

48. ERO, D/DC $27 / 741$.

49. ERO, Q/SR 387/80; ERO, Q/SR 227/49; ERO, D/ABW 50/159.

50. ERO, D/ABW 30/58; ERO, D/ABW 50/159.

51. Morgan, Key and Taylor, eds, Papers of Nathaniel Bacon, volume 4, pp. 101-2.

52. ERO, D/ACW 3/210.

53. ERO, Q/SR $163 / 102$.

54. ERO, Q/SR 207/95 (1614).

55. ERO, Q/SR 211/99; Geoffrey Nightingale was a magistrate.

56. ERO, Q/SR 41/22; William Cache was a juror at Witham Petty Sessions.

57. ERO, Q/SR 204/38; Stephen Nightingale was the constable at Newport Pond.

58. A. Hassell Smith and Gillian M. Baker, eds, The Papers of Nathaniel Bacon of Stiffkey, 15861595, volume 3, (Norwich: Norfolk Record Society, 1988), p. 237; John Burwood son of Margaret was a vicar of Baconsthorpe, Norfolk. NRO, PD 679/1; Richard Burwood, John's son and Margaret's grandson was the curate of Wells, Norfolk.

59. Hilary Marland and G.J. Kloosterman, eds, Mother and Child Were Saved: the Memoirs 1693-1740 of the Frisian Midwife Catharina Schrader (Amsterdam, 1987), p.7, reports that midwife Catharina Schrader practised midwifery for fifty years, until the age of 88 .

60. ERO D/AZ/1/10.

61. Stone, The Family, Sex and Marriage, p. 55, reports expectation of life in the 1640s as 32years.

62. Doreen Evenden, The Midwives of Seventeenth-Century London, (Cambridge, 2000), pp. 106-137.

63. Peter Laslett, The World We Have Lost: Further Explored (London: Methuen, 1965; repr. Abingdon: Routledge, 2005), p. 216.

64. Susan Brigden, New Worlds, Lost Worlds: The Rule of the Tudors 1485-1603 (London: Penguin Books, 2000), p.63. 
65. David Cressy, Agnes Bowker's Cat: Travesties and Transgressions in Tudor and Stuart England (Oxford: Oxford University Press, 2000), p.10.

66. Essex Quarter Session rolls have been transcribed and are no longer available to the public; however a search of one of the rolls by staff at Essex Record Office did not reveal any midwives' signatures.

67. ERO, Q/SR 305/76.

68. ERO, Q/SR 312/124; ERO, Q/SR 363/49; ERO, Q/SR 399/116.

69. W. Weir, 'London Newspapers' in London ed. Charles Knight (London, 1843), volume 5, Chapter CXX11, p. 340, describes the evolution of pamphlets, available in London and other major cities into newspapers in the 1620s.

70. ERO, Q/SR 207/95.

71. Stone, The Family, Sex and Marriage in England 1500-1800, p. 64.

72. Margaret F. Myles, Textbook for Midwives with Modern Concepts of Obstetric and Neonatal care (Edinburgh, 1985), p. 718.

73. David M. Armstrong, 'Birth, Marriage and Death in Elizabethan Cumbria', Fournal of Local Population Studies, 53 (1994), p. 35.

74. Wills of husbands of midwives in the study, were all signed with a mark. Peter Laslett, The World We Have Lost: Further Explored (London, 1965) p. 231.

75. A. Hassell Smith and Gillian M. Baker eds, The Papers of Nathaniel Bacon of Stiffkey, 1556-1577, volume 1, pp. 74-75 and 78 .

76. ERO, D/P 127/1/1; nine women were present at a birth attended by Midwife Mother Wryte in 1569.

77. ERO, Q/SR 69/50; David Cressy, Bonfires and Bells (London,2004) p. 7, St. Stephen the Martyr is celebrated on 26th December and St. Michael the Archangel on 29th September in the Julian calendar.

78. ERO, Q/SR 80/63.

79. ERO, Q/SR $80 / 28$.

80. ERO, Q/SR 36/1/1.

81. ERO, D/P 39/1/1.

82. Jayne Marshall and Maureen Raynor, eds, Myles Textbook for Midwives, 16th edn. (Edinburgh, 2014), p. 116. Lanugo is the fine downy hair on a fetus in utero which begins to disappear from the $36^{\text {th }}$ week of pregnancy.

83. Towler and Bramall Midwives in History and Society, p. 44.

84. ERO, Q/SR 277/49.

85. ERO, D/P 11/1/1.

86. A clyster pipe was used to administer an enema. Decoctions were made from herb extracts.

87. Harley, 'Provincial Midwives'. With a single exception in 1743, Harley was likewise unable to find evidence of how a provincial English woman became recognised as a midwife.

88. F. G. Emmison, Elizabethan Life: Home, Work and Land (Chelmsford, 1976), p. 125.

89. G. B and G. H. Dobbs, A Dictionary of Midwifery and Public Health (London, 1953), p. 305. William Harvey and Percival Willughby claimed that 'the midwives duty in a natural birth is no more but to attend and wait on Nature'.

90. Allison, 'Elizabethan Midwives', pp. 154-84.

91. Donnison, Midwives and Medical Men, p. 21.

92. Adrian Wilson, The Making of Man-midwifery, 1660-1770 (London, 1995), pp. 33-5.

93. ERO, Q/SR104/44. Two unnamed midwives in Pentlow clearly recognised their need for further assistance when they summoned a third midwife, Mother Lamberd, to a difficult birth in 1589.

94. Evenden, The Midwives of Seventeenth-Century London, p. 14, n.75, criticises attempts by a number of academics to establish the annual caseload of sixteenth and seventeenth-century midwives; Allison, Delivered at Home, pp. 7-8, 117-18; midwives' caseloads remained difficult to quantify even into the twentieth century. 
95. SROB, FL501/4/1.

96. Wilson, The Making of Man-midwifery, p. 55.

97. ERO, Q/SR 69/50; ERO, Q/SR 107/44-45.

98. ERO, Q/SR $153 / 29,30$.

99. ERO, D/P 39/1/1; ERO, D/P 113/1/1.

100. Morgan, Key and Taylor, eds, Papers of Nathaniel Bacon, volume 4, p. 101.

101. Lorraine Ashcroft and B. G. Fell, eds, The Diary of A Kendal Midwife: 1669-1675 (Westmoreland, 2001), p. ii contains a map of the widespread area around Kendal where the midwife travelled in order to undertake confinements.

102. Roger Virgoe, ed., Illustrated Letters of the Paston Family (London, 1989), p. 96; A. H. Dodd, Life in Elizabethan England (London, 1961), pp. 140-51.

103. ERO, Q/SR 113/40; ERO, Q/SR 189/36; ERO, Q/SR 103/14.

104. ERO, Q/SR 148/139.

105. ERO, Q/SR 46/1; ERO, Q/SR 180/46; these are examples of numerous jury presentments regarding the parlous state of the highways and bridges in East Anglia.

106. Wilson, The Making of Man-midwifery, p. 34, makes the assumption that villages with ten to twenty births a year usually had their own midwife so that midwives gained little experience of difficult births.

107. ERO, Q/SR 80/53; ERO, D/P 36/1/1.

108. ERO, Q/SR 104/59 a; ERO, D/P 113/1/1.

109. ERO, Q/SR 107/44-45.

110. ERO, Q/SR 107/44-45.

111. ERO, Q/SR 104/59 a.

112. ERO, Q/SR $107 / 45$.

113. ERO, D/P 109/1/1.

114. ERO, Q/SR160/17.

115. ERO, Q/SR/84/44.

116. ERO, D/P 109/1/1.

117. ERO, D/P 25/1/1.

118. ERO, D/P 109/1/1.

119. Emmison, Elizabethan Life: Morals and the Church Courts, p. 320.

120. Alan Macfarlane, Witchcraft in Tudor and Stuart England: A Regional and Comparative Study (London, 1970) reports that Essex Assizes records contain some 503 indictments under the Witchcraft Statute between 1560-1680; ERO, T/A 418/41/43; ERO, Q/SR 110/70.

121. Jane Sharp, The Midwives Book or The Whole Art of Midwifry (1671), ed. Elaine Hobby (Oxford, 1999), p. 297, demonstrates the concern felt by midwives, even into the seventeenth century, when she advises prayer as 'the best remedy' for an infant who was lean and pining away from witchcraft.

122. Baker and Smith, Papers of Nathaniel Bacon, volume 1, p. 81.

123. Ibid., p. 200.

124. ERO, D/P 109/1/1.

125. ERO, Q/SR 80/53.

126. ERO, D/P 163/1/1; ERO, D/DC/27/741.

127. ERO, D/P 243/1/1.

128. ERO, T/A 418/88/44.

129. ERO, Q/SR/225/123; ERO, Q/SR 249/97.

130. ERO, Q/SR 328/117.

131. ERO, Q/SR $415 / 96$.

132. ERO, Q/SR $80 / 53$.

133. ERO, Q/SR 211/99.

134. See pp. 000 .

135. F. G. Emmison, Elizabethan Life: Disorder (Chelmsford, 1970), p. 157. 